\title{
RASIO TEPUNG TAPIOKA, TEPUNG KETAN DAN TEPUNG UBI JALAR UNGU TERHADAP SIFAT FISIKOKIMIA DODOL
}

\author{
[Ratio of Tapioca Flour, Glutinous Flour and Purple Sweet Potato Flour on the Physicochemicals \\ Properties of Dodol]
}

\author{
Solihatun Hafizah*, Ahmad Alamsyah, Yeni Sulastri \\ Program Studi IImu dan Teknologi Pangan, Fakultas Teknologi Pangan dan Agroindustri, Universitas Mataram \\ *Email: Solihatunhafizah@gmail.com
}

Diterima 9 Juli 2018/ Disetujui Oktober 2018

\begin{abstract}
The purpose of this research was to determine the effect of the ratio of tapioca flour, glutinous flour and purple sweet potato flour to the physicochemical properties of dodol with chemical quality (moisture content, total anthocyanin, and reduction sugar) and physical quality of the color ( $L$ value and ${ }^{\circ}$ Hue value). This study used Randomized Block Design (RBD) consisting of 6 treatments T1= Tapioca Flour 80\%: Glutinous Flour 10\%: Purple Sweet Potato Flour 10\%, T2= Tapioca Flour 70\%: Glutinous Flour 15\%: Purple Sweet Potato Flour 15\%, T3= Tapioca Flour 60\%: Glutinous Flour 20\%: Purple Sweet Potato Flour 20\%, T4=Tapioca Flour 50\%: Glutinous Flour 25\%: Purple Sweet Potato Flour 25\%, T5= Tapioca Flour 40\%: Glutinous Flour 30\%: Purple Sweet Potato Flour 30\%, T6= Tapioca Flour 30\%: Glutinous Flour 35\%: Purple Sweet Potato Flour 35\% with 3 times repetitions. The data of the research were analyzed using the diversity analysis at $5 \%$ level using Co-stat software and tested continued using the test of Honest Real Difference (HRD) if there was real difference. The results showed that the ratio of tapioca flour, glutinous flour and purple sweet potato flour gave a significantly different effect on chemical quality (moisture content, total anthocyanin, and reduction sugar), and physical quality of the color (oHue value) but gave no significant effect on physical quality of the color ( $L$ value). The result showed that the ratio of tapioca flour 30\%: glutinous flour 35\%: purple sweet potato flour $35 \%$ was the best treatment with moisture contect of $24.21 \%$, total anthocyanin $8.48 \mathrm{mg} / 100 \mathrm{~g}$, reducing sugar $7.83 \%, L$ value of 23.85 and ${ }^{\circ}$ Hue value 360.14
\end{abstract}

Keywords: dodol, glutinous flour, tapioca flour, purple sweet potato flour

\begin{abstract}
ABSTRAK
Tujuan dari penelitian ini adalah untuk mengetahui pengaruh rasio tepung tapioka, tepung ketan dan tepung ubi jalar ungu terhadap sifat fisikokimia dodol dengan kualitas kimia (kadar air, total antosianin, dan kadar gula reduksi) dan mutu fisik warna (nilai $L$ dan nilai ${ }^{\circ}$ Hue). Penelitian ini menggunakan Rancangan Acak Kelompok (RAK) yang terdiri dari 6 perlakuan T1= Tepung Tapioka 80\% :Tepung Ketan 10\%:Tepung Ubi Jalar Ungu 10\%, T2= Tepung Tapioka 70\% :Tepung Ketan 15\% :Tepung Ubi Jalar Ungu 15\%, T3= Tepung Tapioka 60\% :Tepung Ketan 20\% :Tepung Ubi Jalar Ungu 20\%, T4= Tepung Tapioka 50\% :Tepung Ketan 25\% :Tepung Ubi Jalar Ungu 25\%, T5= Tepung Tapioka 40\% :Tepung Ketan 30\% :Tepung Ubi Jalar Ungu 30\%, T6= Tepung Tapioka 30\% :Tepung Ketan 35\% :Tepung Ubi Jalar Ungu 35\% dengan 3 kali pengulangan. Data hasil penelitian dianalisis menggunakan analisis keragaman pada taraf $5 \%$ menggunakan software Co-stat dan diuji lanjut menggunakan uji Beda Nyata Jujur (BNJ) jika terdapat beda nyata. Hasil penelitian menunjukkan bahwa rasio tepung tapioka, tepung ketan dan tepung ubi jalar ungu memberikan pengaruh yang berbeda nyata terhadap mutu kimia (kadar air, total antosianin dan gula reduksi) dan mutu fisik warna (nilai oHue) namun memberikan pengaruh yang tidak berbeda nyata terhadap mutu fisik warna (nilai L). Berdasarkan hasil penelitian menunjukkan bahwa rasio tepung tapioka (30\%), tepung ketan (35\%) dan tepung ubi jalar ungu (35\%) merupakan perlakuan terbaik dengan kadar air sebesar $24,21 \%$, total antosianin $8,48 \mathrm{mg} / 100 \mathrm{~g}$, gula reduksi $7,83 \%$, nilai L sebesar 23,85 dan nilai oHue 360,14.
\end{abstract}

Kata Kunci: dodol, tepung ketan, tepung tapioka, tepung ubi jalar ungu.

\section{PENDAHULUAN}

Dodol merupakan suatu olahan pangan yang dibuat dari campuran tepung ketan, gula pasir, dan santan kelapa, yang dididihkan hingga menjadi kental, berminyak, dan tidak lengket. Apabila didinginkan pasta akan menjadi padat, kenyal dan dapat diiris. Jenis dodol sangat beragam tergantung keragaman campuran tambahan dan juga cara pembuatannya (Haryadi, 2006).

Menurut Nirvana (2013), saat ini permintaan pasar untuk dodol sangat tinggi 
Versi Online:

http://wWw.profood.unram.ac.id/index.php/profood e-ISSN: 2443-3446

karena kerap dijadikan buah tangan dari Lombok. Banyak para pengunjung yang berasal dari luar Lombok yang membeli produk dodol sebagai buah tangan yang memiliki harga yang dapat dijangkau oleh semua kalangan. Oleh karena itu, bahan baku dalam pembuatan dodol perlu diperhatikan karena akan mempengaruhi mutu dodol yang dihasilkan.

Dodol biasanya terbuat dari bahan utama yaitu tepung ketan yang didasarkan atas sifat tepung ketan yang hampir seluruhnya terdiri dari amilopektin. Sifat amilopektin ini memperkuat pengikatan air dengan baik (Soekarto, 1979). Selain kandungan amilopektin yang meningkat, kestabilan tepung ketan sebagai pengental juga disebabkan oleh penyimpangan struktur kimia atau oleh kecilnya ukuran granula pati. Amilopektin merupakan molekul yang bercabang, sehingga molekul air yang terkait padanya tidak mudah lepas. Hal ini menyebabkan stabilnya produk selama penyimpanan (Houston, 1972).

Tepung ketan adalah tepung yang terbuat dari beras ketan hitam atau putih yang diolah dengan cara digiling, ditumbuk atau dihaluskan. Teksturnya mirip dengan tepung beras, namun terasa lebih lengket. Komponen utama tepung ketan adalah kandungan nutrisi yang terdiri dari vitamin, protein, lemak, mineral, abu, dan pati. Nadia (2010) menyatakan bahwa kelemahan penggunaan $100 \%$ tepung ketan pada pembuatan dodol akan menghasilkan tekstur dodol yang terlalu liat. Hal ini diakibatkan karena kandungan amilopektin pada tepung ketan yang tinggi yaitu sebesar $98 \%$ sehingga mengakibatkan viskositas yang tinggi dan membentuk tekstur dodol menjadi liat. Selain adanya amilopektin, amilosa juga berperan dalam pembentukan tekstur dodol, amilosa akan memberikan tekstur keras dan kering, sehingga apabila kandungan amilosa terlalu tinggi akan membentuk tekstur keras pada produk dodol.

Selain itu, menurut Tangketasik (2013) mengenai produk dodol menyatakan bahwa, perlakuan dengan menggunakan tepung ketan dan tepung tapioka dengan
Pro Food (Jurnal IImu dan Teknologi Pangan)

Vol 4 No. 2 November 2018

ISSN: 2443-1095

perbandingan $10 \% \quad$ : $90 \%$ menghasilkan dodol dengan nilai organoleptik terbaik berdasarkan tekstur, rasa dan warna. Sementara itu, menurut Sri, et., al (2010), penambahan tepung tapioka sebagai substitusi tepung ketan sangatlah penting karena sifatnya sebagai bahan pengikat (binding agent) terhadap bahan-bahan lain yang dapat menghasilkan tekstur dodol susu yang plastis, kompak, dan meningkatkan emulsi, sehingga dapat mengurangi kerapuhan.

Tepung tapioka adalah tepung yang dibuat dari hasil penggilingan ubi kayu yang dibuang ampasnya. Ubi kayu tergolong polisakarida yang mengandung pati dengan kandungan amilopektin $83 \%$ dan amilosa 17\% (Tangketasik, 2013), sehingga dapat dijadikan sebagai pengganti sebagian tepung ketan dalam pembuatan dodol. Kedua tepung tersebut dapat disubsitusikan dengan tepungtepungan yang lain agar dalam pengolahan suatu produk makanan kandungan gizi di dalamnya menjadi lengkap dan bermanfaat bagi tubuh seperti tepung ubi jalar ungu.

Ubi jalar ungu merupakan salah satu jenis ubi jalar yang terdapat di Indonesia. Ubi jalar ungu memiliki daging berwarna ungu ada yang berwarna ungu muda dan berwarna ungu pekat. Ubi jalar ungu memiliki keunggulan, salah satunya mengandung antioksidan yang sangat berguna bagi tubuh dan pigmen antosianin yang lebih tinggi dari sumber lain seperti kubis ungu, blueberrry dan jagung merah. Menurut Rosidah (2010) kadar antosianin dalam ubi jalar ungu sebesar $110,51 \mathrm{mg} / 100 \mathrm{~g}$. Dengan tingginya kandungan antosianin dapat meningkatkan nilai gizi dodol. Menurut Widowati dan Sunihardi (2000) dalam Huri (2012), penggunaan tepung ubi jalar sebagai tepung komposit pada pembuatan dodol antara 30 $50 \%$.

Sejauh ini, penelitian tentang penggunaan kombinasi ketiga jenis tepung (tepung tapioka, tepung ketan dan tepung ubi jalar ungu) dalam pembuatan dodol belum pernah dilakukan, sehingga belum diketahui pengaruhnya terhadap sifat fisik, kimia dan organoleptik dodol. Oleh karena itu, telah 
Versi Online:

http://www.profood.unram.ac.id/index.php/profood e-ISSN: 2443-3446

dilakukan penelitian tentang "Rasio Tepung Tapioka, Tepung Ketan dan Tepung Ubi Jalar Ungu Terhadap Sifat Fisikokimia Dodol".

\section{BAHAN DAN METODE}

\section{Alat dan Bahan}

Alat-alat yang digunakan dalam penelitian ini antara lain pisau stainless steel, baskom, sendok pengaduk, gelas ukur, wajan, kompor, cabinet dryer, calorimeter (MSEZ User Manual), blender, ayakan 100 mesh, tabung erlenmeyer, stopwatch, botol timbang, kain saring, labu ukur, pipet ukur, timbangan analitik, sendok, gunting, loyang, evaporator, desikator, batang pengaduk, gelas piala, penggaris, kamera, cawan porselin, spektrofotometer, tebung reaksi, plastik klip, batu didih, rak tabung reaksi, centrifuge, kertas label, tissu, hot plate dan alat tulis.

Bahan-bahan yang digunakan dalam penelitian ini adalah tepung ubi ungu, tepung ketan merk Rose Brand, tepung tapioka merk Rose Brand, garam, santan merk Kara, air, gula pasir, vanili, aquadest, larutan buffer $\mathrm{KCl}$, buffer Na-Asetat, larutan Nelsion, Kl 20\%, iodium, Na-tiosulfat $0,1 \mathrm{~N}$, indikator amilum, $\mathrm{NaOH} 20 \%$, reagensia Arsenomolybdat, reagensia Nelsion, larutan $\mathrm{H}_{2} \mathrm{SO}_{4}, 26,5 \%$,

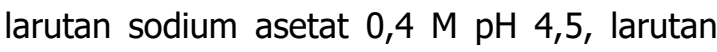
potasium klorida $(0,025 \mathrm{M}) \mathrm{pH} 1,15 \% \mathrm{HCl}$ $1,5 \mathrm{~N}$ dan $85 \%$ methanol.

\section{Metode}

Metode yang digunakan dalam penelitian ini adalah metode eksperimental yang dilaksanakan di Laboratorium. Rancangan percobaan yang akan digunakan dalam penelitian ini adalah Rancangan Acak Kelompok (RAK) dengan percobaan tunggal yaitu rasio tepung tapioka, tepung ketan dan tepung ubi jalar ungu. Masing-masing perlakuan diulang sebanyak 3 kali sehingga diperoleh 18 unit percobaan. Data hasil pengamatan dianalisa menggunakan analisa keragaman (Analysis of Variance) pada taraf nyata $5 \%$ dengan menggunakan software Costat. Bila ada perlakuan yang berbeda nyata, maka dilakukan uji lanjut menggunakan Beda Nyata Jujur (Hanafiah, 2003).
Pro Food (Jurnal IImu dan Teknologi Pangan) Vol 4 No. 2 November 2018 ISSN: 2443-1095

Parameter yang dianalisa meliputi mutu kimia yaitu kadar air (Sudarmadji, dkk., 1997), total antosianin (Giusti dan Wrolstad, 2001), kadar gula reduksi (Sudarmadji, dkk., 1997), dan mutu fisik (warna) (Andarwulan, $\mathrm{dkk}$, 2011).

\section{Proses Pembuatan Dodol}

1. Persiapan bahan baku

Bahan baku yang digunakan adalah tepung ketan, tepung tapioka, dan tepung ubi jalar ungu dengan berat total 400 gram. Adapun konsentrasi bahan yang akan digunakan dalam penelitian yaitu tepung tapioka merk Rose Brand sebanyak 80\% (320 g), $70 \%(280 \mathrm{~g}), 60 \%(240 \mathrm{~g}), 50 \%(200 \mathrm{~g})$, 40\% (160 g), 30\% (120 g), tepung ketan merk Rose Brand sebanyak 10\% (40 g), 15\% $(60 \mathrm{~g}), 20 \%$ (80 g), 25\% (100 g), 30\% (120 g), 35\% (140 g), sedangkan tepung ubi jalar ungu sebanyak $10 \%(40 \mathrm{~g}), 15 \%(60 \mathrm{~g})$, $20 \%$ (80 g), 25\% (100 g), 30\% (120 g), 35\% $(140 \mathrm{~g})$, bahan tambahan yang digunakan gula pasir sebanyak $140 \mathrm{~g}$, garam sebesar 3 $\mathrm{g}$, vanili $1 \mathrm{~g}$, air $800 \mathrm{~g}$ dan santan merk Kara $300 \mathrm{~g}$.

2. Pencampuran

Pencampuran bahan baku utama (tepung ketan, tepung tapioka dan tepung ubi jalar ungu) dan bahan tambahan (gula, garam, vanili, air dan santan) untuk setiap perlakuan dicampur dan diaduk hingga rata.

3. Pemasakan

Bahan yang telah tercampur rata, kemudian dimasak dengan suhu $\pm 75^{\circ} \mathrm{C}$ sambil diaduk selama 2 jam. Pemasakan dihentikan apabila sudah kalis dengan ciri-ciri adonan tidak lengket pada tangan atau wajan yang digunakan.

4. Pendinginan

Setelah pemasakan dodol harus segera dipindahkan ke loyang dengan tinggi 1 $\mathrm{cm}$ agar tidak gosong. Proses pendinginan dilakukan dalam loyang yang telah beralaskan plastik untuk memudahkan pada waktu pelepasan dodol dari tempatnya. Pendinginan dilakukan selama 12 jam dengan suhu 30 ${ }^{\circ} \mathrm{C}$ dengan tujuan agar dodol mudah diiris dan dibentuk.

5. Pemotongan 
Versi Online:

http://wWw.profood.unram.ac.id/index.php/profood e-ISSN: 2443-3446

Dodol dipotong dengan pisau stainlees still dengan ukuran $3 \mathrm{~cm} \times 1 \mathrm{~cm} \times 1$ $\mathrm{cm}$.

\section{Pengeringan}

Dodol yang telah diiris selanjutnya dimasukkan ke dalam cabinet dryer bersuhu $40{ }^{\circ} \mathrm{C}$ selama 3 jam untuk mengurangi kadar air dodol. Kemudian dodol dianalisa kadar air, total antosianin, gula reduksi, dan uji fisik (warna).

\section{HASIL DAN PEMBAHASAN}

\section{Mutu Kimia}

Tabel 1. Analisis Keragaman Pengaruh Rasio Tepung Tapioka, Tepung Ketan dan Tepung Ubi Jalar Ungu Terhadap Mutu Kimia Dodol

\begin{tabular}{|c|c|}
\hline Parameter & Signifikansi \\
\hline Kadar Air & $\mathrm{S}$ \\
\hline Total Antosianin & $S$ \\
\hline Gula Reduksi & S \\
\hline $\begin{array}{ll}\text { Keterangan: } & =\mathrm{Sig} \\
\mathrm{NS} & =\mathrm{No}\end{array}$ & $\begin{array}{l}\text { seda nyata) } \\
\text { (tidak berbeda nyata) }\end{array}$ \\
\hline
\end{tabular}

\section{Kadar Air}

Kadar air merupakan salah satu mutu kimia yang menunjukkan banyaknya air dalam bahan pangan yang dinyatakan dalam persen. Kadar air juga salah satu parameter penting dalam menentukan kualitas bahan pangan karena kadar air dapat mempengaruhi penampakan, tekstur dan cita rasa pada bahan pangan. Kadar air dalam bahan pangan ikut menentukan kesegaran dan daya awet bahan pangan tersebut. Kadar air yang tinggi menyebabkan mudahnya bakteri, kapang, dan khamir untuk berkembang biak, sehingga akan terjadi perubahan pada bahan pangan (Dwijoseputro,1994).

Berdasarkan hasil analisis dan keragaman pada dodol menunjukkan bahwa rasio tepung tapioka, tepung ketan dan tepung ubi jalar ungu memberikan pengaruh yang berbeda nyata terhadap kadar air dodol. Pengaruh rasio tepung tapioka, tepung ketan dan tepung ubi jalar ungu terhadap kadar air dodol dapat dilihat pada Gambar 1.

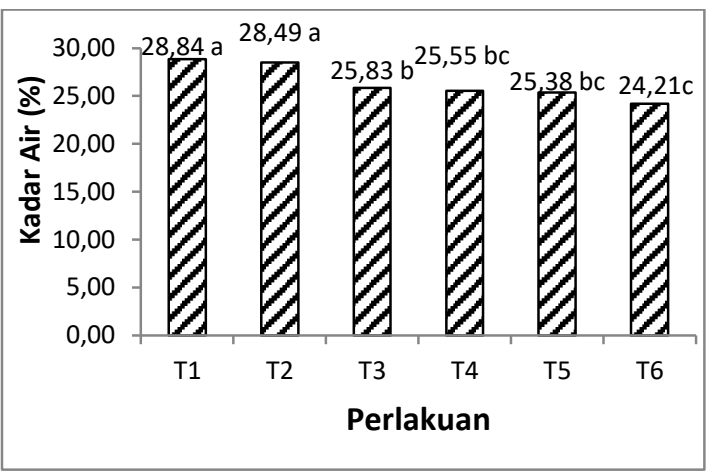

Gambar 1. Pengaruh Rasio Tepung Tapioka, Tepung Ketan dan Tepung Ubi Jalar Ungu Terhadap Kadar Air Dodol

Keterangan

T1= Tepung Tapioka 80\% :Tepung Ketan 10\% :Tepung Ubi Jalar Ungu 10\% T2= Tepung Tapioka 70\%:Tepung Ketan 15\%:Tepung Ubi Jalar Ungu 15\% T3= Tepung Tapioka 60\%:Tepung Ketan 20\%:Tepung Ubi Jalar Ungu $20 \%$ T4= Tepung Tapioka 50\% :Tepung Ketan 25\% :Tepung Ubi Jalar Ungu 25\% T5= Tepung Tapioka 40\% :Tepung Ketan 30\% :Tepung Ubi Jalar Ungu 30\% T6= Tepung Tapioka 30\% :Tepung Ketan 35\% :Tepung Ubi Jalar Ungu 35\%

Gambar 1 menunjukkan bahwa rasio tepung tapioka, tepung ketan dan tepung ubi jalar ungu memberikan pengaruh yang berbeda nyata terhadap kadar air dodol. Kadar air tertinggi diperoleh pada perlakuan T1 dengan rasio tepung tapioka $80 \%$, tepung ketan $10 \%$ dan tepung ubi jalar ungu $10 \%$ yaitu sebesar $28,84 \%$. Nilai kadar air terendah diperoleh pada perlakuan T6 dengan rasio tepung tapioka $30 \%$, tepung ketan $35 \%$ dan tepung ubi jalar ungu 35\% yaitu sebesar $24,12 \%$. Dari grafik tersebut dapat diketahui bahwa semakin rendah tepung tapioka yang ditambahkan pada dodol maka kadar air yang dihasilkan semakin menurun. Hal ini diduga bahwa tepung yang memiliki kadar pati yang rendah memiliki daya serap air yang rendah. Kadar air pada produk dodol akan meningkat jika konsentrasi tepung tapioka yang ditambahkan semakin banyak. Hal ini diduga karena pati yang terkandung dalam tepung tapioka memiliki sifat menyerap air. Hal ini juga sesuai dengan pernyataan Winarno (2004), tepung yang memiliki kadar pati yang tinggi memiliki daya serap air yang besar, karena pada ujung rantai molekul amilosa dan amilopektin terdapat gugus hidroksil yang terdapat dalam sistem dispersi air dan pati, maka gugus hidroksil tersebut berinteraksi dengan gugus hidrogen dari air dan sebaliknya. Adapun kadar pati tepung tapioka 
Versi Online:

http://www.profood.unram.ac.id/index.php/profood e-ISSN: 2443-3446

sebesar 65,26\%, tepung ketan sebesar 63,31\% (Imanningsih, 2012).

Selain pengaruh kandungan pati, kadar air dodol juga kemungkinan dipengaruhi oleh kadar air bahan baku yang digunakan. Bahan baku mempunyai kadar air bervariasi, yaitu pada tepung tapioka sebesar $15,76 \%$, tepung ketan sebesar $13,75 \%$ dan tepung ubi jalar ungu 10,61\%. Semakin banyak tepung ubi jalar ungu yang ditambahkan maka kadar air dodol semakin menurun. Menurut Standar Nasional Indonesia (SNI) (1992), kadar air dodol adalah maksimum 20\%, sehingga kadar air pada dodol hasil penelitian belum memenuhi syarat SNI dodol.

\section{Total Antosianin}

Antosianin merupakan salah satu dari sekian banyak pigmen yang terdapat di alam. Antosianin dapat memberikan warna yang bervariasi dari biru ke merah (Yahya, 2010). Penambahan tepung ubi jalar ungu pada produk dodol selain memberikan karakteristik warna yang menarik, juga dapat memberikan manfaat kesehatan bagi tubuh. Menurut Suda et al., (2003), ubi jalar ungu varietas ayamurasaki memiliki aktivitas antioksidan, dapat mengatur tekanan darah, dan dapat berperan sebagai anti-mutagenik. Pengaruh rasio tepung tapioka, tepung ketan dan tepung ubi jalar ungu terhadap total dodol dapat dilihat pada Gambar 2.

Gambar 2 menunjukkan bahwa adanya pengaruh yang berbeda nyata terhadap total antosianin pada produk dodol yang dihasilkan. Total antosianin tertinggi diperoleh pada dodol yang dibuat dari campuran tepung tapioka $30 \%$, tepung ketan $35 \%$ dan tepung ubi jalar ungu $35 \%$ yaitu sebesar $8,48 \mathrm{mg} / 100 \mathrm{~g}$, sedangkan total antosianin terendah diperoleh pada dodol yang dibuat dari campuran tepung tapioka $80 \%$, tepung ketan $10 \%$ dan tepung ubi jalar ungu $10 \%$ yaitu sebesar $5,18 \mathrm{mg} / 100 \mathrm{~g}$. Hal ini disebabkan semakin banyak penambahan tepung ubi jalar ungu, maka total antosianin dodol akan semakin meningkat. Sesuai dengan pernyataan Hairani (2017) semakin
Pro Food (Jurnal IImu dan Teknologi Pangan) Vol 4 No. 2 November 2018 ISSN: 2443-1095

tinggi konsentrasi penambahan tepung ubi jalar ungu, semakin tinggi pula total antosianin sosis analog tempe. Peningkatan total antosianin juga terjadi pada minuman ubi ungu seiring dengan peningkatan konsentrasi penambahan tepung ubi jalar ungu (Ticoalu, 2016). Hal ini juga sejalan dengan penelitian Fadhilah (2011), semakin banyak tepung ubi jalar ungu yang digunakan, maka semakin tinggi kandungan zat antosianin pada roti tawar. Sebelumnya telah dianalisis total antosianin tepung ubi jalar ungu yang digunakan dalam penelitian ini dan diperoleh hasil $35,77 \mathrm{mg} / 100 \mathrm{~g}$.

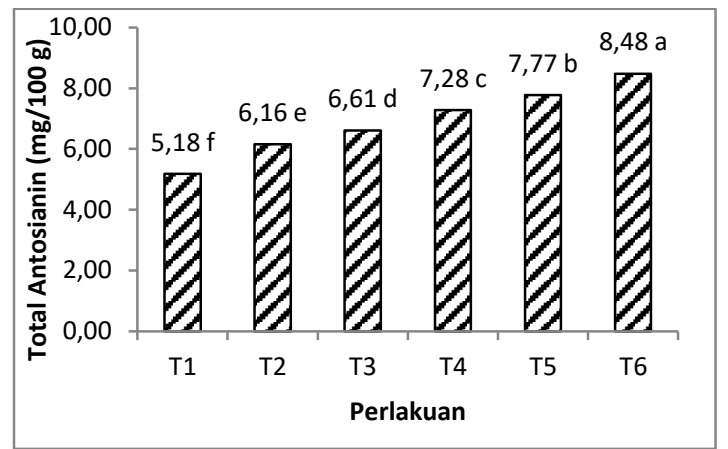

Gambar 2. Pengaruh Rasio Tepung Tapioka, Tepung Ketan dan Tepung Ubi Jalar Ungu Terhadap Total Antosianin Dodol

Keterangan

T1= Tepung Tapioka 80\% :Tepung Ketan 10\% :Tepung Ubi Jalar Ungu $10 \%$ T2= Tepung Tapioka 70\%: Tepung Ketan 15\%:Tepung Ubi Jalar Ungu $15 \%$ T2 $=$ Tepung Tapioka 70\% :Tepung Ketan 15\%:Tepung Ubi Jalar Ungu $15 \%$
T3= Tepung Tapioka 60\% :Tepung Ketan 20\% :Tepung Ubi Jalar Ungu $20 \%$ T4= Tepung Tapioka 50\% :Tepung Ketan 25\%:Tepung Ubi Jalar Ungu 25\% T5= Tepung Tapioka 40\%:Tepung Ketan 30\% :Tepung Ubi Jalar Ungu 30\% T6= Tepung Tapioka 30\% :Tepung Ketan 35\% :Tepung Ubi Jalar Ungu 35\%

\section{Kadar Gula Reduksi}

Gula reduksi merupakan senyawa penting dari karbohidrat yang mempunyai peran utama dalam penyediaan kalori bagi makhluk hidup dan merupakan senyawa utama yang dapat dijumpai pada tumbuhtumbuhan. Kadar gula reduksi yang tinggi dalam suatu bahan pangan ditandai dengan rasanya yang manis. Dengan demikian semakin manis rasa suatu produk maka semakin tinggi kadar gula reduksinya (Hairani, 2017). Pada penelitian ini, kadar gula reduksi dodol mengalami peningkatan seiring dengan peningkatan penambahan tepung ubi jalar ungu. Pengaruh rasio tepung tapioka, tepung ketan dan tepung ubi jalar ungu terhadap kadar gula reduksi dodol dapat dilihat pada Gambar 3. 


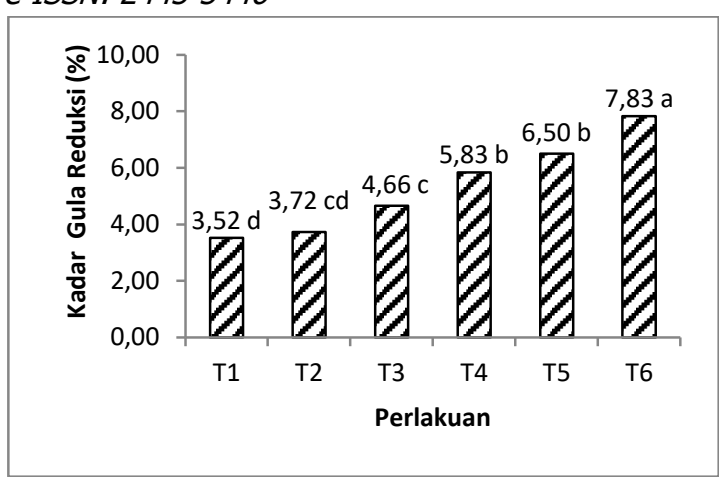

Gambar 3. Pengaruh Rasio Tepung Tapioka, Tepung Ketan dan Tepung Ubi Jalar Ungu Terhadap Kadar Gula Reduksi Dodol

Keterangan:

T1= Tepung Tapioka 80\% :Tepung Ketan 10\% :Tepung Ubi Jalar Ungu 10\% T2= Tepung Tapioka 70\% :Tepung Ketan 15\%:Tepung Ubi Jalar Ungu 15\% T3= Tepung Tapioka 60\% :Tepung Ketan 20\%:Tepung Ubi Jalar Ungu 20\% T4= Tepung Tapioka 50\% :Tepung Ketan 25\% :Tepung Ubi Jalar Ungu 25\% T5= Tepung Tapioka 40\% :Tepung Ketan 30\% :Tepung Ubi Jalar Ungu 30\% T6= Tepung Tapioka 30\% :Tepung Ketan 35\% :Tepung Ubi Jalar Ungu 35\%

\section{Gambar 3 menunjukkan bahwa} adanya pengaruh yang berbeda nyata terhadap gula reduksi dodol. Hal ini diduga disebabkan oleh jumlah karbohidrat pada bahan baku yang digunakan. Kadar gula reduksi yang paling tinggi diperoleh pada perlakuan dengan rasio tepung tapioka $30 \%$, tepung ketan $35 \%$ dan tepung ubi jalar ungu $35 \%$ yaitu sebesar $7,83 \%$, sedangkan kadar gula reduksi terendah diperoleh pada perlakuan dengan rasio tepung tapioka $80 \%$, tepung ketan $10 \%$ dan tepung ubi jalar ungu $10 \%$ yaitu sebesar $3,52 \%$.

Berdasarkan hasil penelitian kandungan gula reduksi pada dodol sangat dipengaruhi oleh kadar air, jika kadar air pada suatu makanan tinggi, maka kandungan lainnya menurun, begitu juga kandungan gula reduksi. Menurut hasil penelitian Yani (2006), konsentrasi kadar gula reduksi yang cukup tinggi akan menyebabkan terjadinya penetrasi gula reduksi tersebut ke dalam bahan dan tertariknya air keluar bahan. Hal ini disebabkan oleh adanya sifat hidroskopis gula yang berkaitan dengan air yang terdapat dalam dodol sehingga jumlah kadar gula reduksi dalam bahan berubah atau bertambah, bertambahnya kadar gula reduksi pada bahan akan menurunkan kadar air.

Menurut Winarno (2004) menyatakan bahwa peningkatan kadar gula reduksi erat kaitannya dengan kandungan bahan
ISSN: 2443-1095

khususnya karbohidrat yaitu seperti tepung ketan yang mengandung karbohidrat yang tinggi yaitu sebesar $81,05 \%$. Kandungan karbohidrat pada tepung tapioka dan ubi jalar ungu juga cukup tinggi. Karbohidrat pada tepung ubi jalar ungu yaitu sebesar $84,74 \%$ dan tepung tepung tapioka yaitu sebesar 78,13\% (Antarlina, 1998; Imanningsih, 2012). Hal ini diduga mengakibatkan meningkatnya kadar gula reduksi pada dodol. Sesuai dengan pernyataan Rumahrupute dan Corneles (2010), menyatakan bahwa meningkatnya kadar gula reduksi pada dodol pala disebabkan oleh adanya penambahan tepung ketan dan menghasilkan produk dodol terbaik pada perlakuan dengan konsentrasi tepung ketan 30\% dengan jumlah gula reduksi yaitu sebesar 1,86\%. Menurut Gaman dan Sherrington (1994) dalam Kelmaskosu et al (2015) menyatakan bahwa meningkatnya kadar gula reduksi pada dodol pepaya disebabkan oleh adanya penambahan tepung ketan. Komponen terbesar tepung ketan adalah karbohidrat, dimana mengadung glukosa yang menyumbangkan gula reduksi pada dodol. Jadi semakin banyak penambahan tepung ketan, maka kandungan glukosa akan naik dan meningkatkan gula reduksi.

\section{Mutu Fisik}

Tabel 2. Analisis Keragaman Pengaruh Rasio Tepung Tapioka, Tepung Ketan dan Tepung Ubi Jalar Ungu Terhadap Mutu Fisik Dodol

\begin{tabular}{|c|c|}
\hline Parameter & Signifikansi \\
\hline Nilai L & NS \\
\hline Nilai 애ue & $S$ \\
\hline
\end{tabular}

\section{Warna L dan ${ }^{\circ} \mathrm{Hue}$}

Pada bahan makanan warna merupakan faktor yang ikut menentukan mutu, selain itu warna juga dapat digunakan sebagai indikator kesegaran atau kematangan. Baik tidaknya cara pencampuran atau cara pengolahan dapat ditandai dengan adanya warna yang seragam dan merata. Warna bahan makanan biasa diukur dengan 
Versi Online:

http://Www.profood.unram.ac.id/index.php/profood e-ISSN: 2443-3446

urut $\mathrm{L}^{*} \mathrm{a}^{*} \mathrm{~b}^{*}$ yang merupakan standar internasional pengukuran warna, diadopsi oleh CIE (Commission Internationale d'Eclairage). Penerangan atau Lightness berkisar antara 0 dan 100 sedangkan parameter kromatik $(a, b)$ berkisar antara -120 dan 120. Nilai a menunjukkan warna kromatik antara +10 dan +100 dengan intensitas warna merah dan -0 sampai -80 dengan intensitas warna hijau. Nilai b menunjukkan warna kromatik antara +10 sampai +100 dengan intensitas warna kuning dan -0 sampai -80 dengan intensitas warna biru (Gokmen et al., 2007). Nilai a dan b akan membentuk sebuah warna dengan menentukan nilai oHue. Pengaruh rasio tepung tapioka, tepung ketan dan tepung ubi jalar ungu terhadap nilai $\mathrm{L}$ dodol dapat dilihat pada Gambar 4.

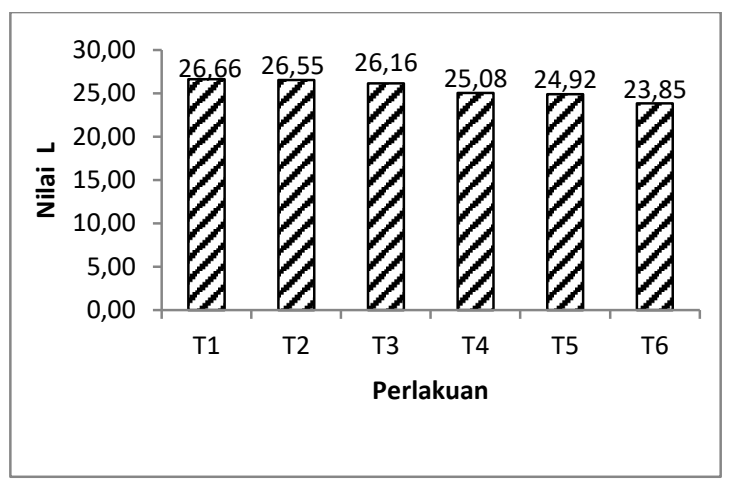

Gambar 4. Pengaruh Rasio Tepung Tapioka, Tepung Ketan dan Tepung Ubi Jalar Ungu Terhadap Warna L Dodol

Keterangan:

T1= Tepung Tapioka 80\% :Tepung Ketan 10\% :Tepung Ubi Jalar Ungu 10\% T2= Tepung Tapioka 70\%:Tepung Ketan 15\%:Tepung Ubi Jalar Ungu 15\% T3= Tepung Tapioka 60\% :Tepung Ketan 20\% :Tepung Ubi Jalar Ungu 20\% T4= Tepung Tapioka 50\% :Tepung Ketan 25\% :Tepung Ubi Jalar Ungu 25\% T5= Tepung Tapioka 40\% :Tepung Ketan 30\% :Tepung Ubi Jalar Ungu 30\% T6= Tepung Tapioka 30\% :Tepung Ketan 35\% :Tepung Ubi Jalar Ungu 35\%

Gambar 4 menunjukkan bahwa adanya pengaruh yang tidak berbeda nyata terhadap nilai $\mathrm{L}$ dodol yang dihasilkan. Jika dilihat dari purata tingkat kecerahan atau nilai $L$ yang diperoleh adalah berkisar antara 23,85-26,66 hal ini menunjukkan tingkat kecerahan dodol rendah. Untuk nilai L berkisar antara 0 sampai 100 . Nilai 0 adalah warna hitam sedangkan nilai 100 merupakan warna putih, sehingga semakin tinggi warna $\mathrm{L}$ yang diperoleh maka semakin cerah warna produk tersebut begitu juga sebaliknya.
Pro Food (Jurnal IImu dan Teknologi Pangan)

Vol 4 No. 2 November 2018

ISSN: 2443-1095

Pengaruh rasio tepung tapioka, tepung ketan dan tepung ubi jalar ungu terhadap ${ }^{\circ}$ Hue dodol dapat dilihat pada Gambar 5.

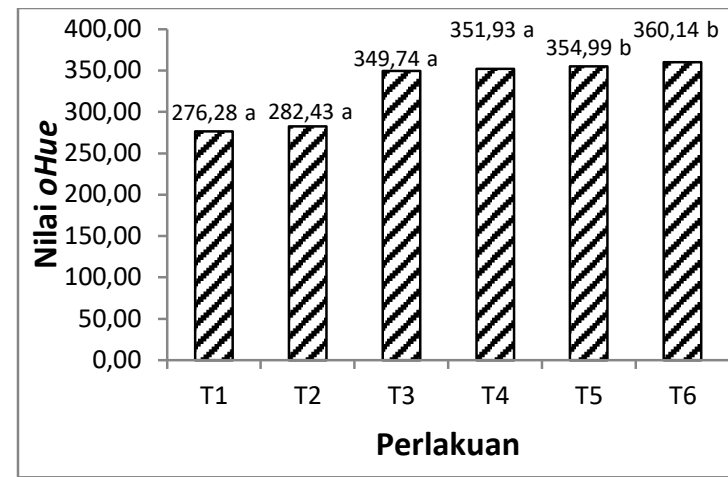

Gambar 5. Pengaruh Rasio Tepung Tapioka, Tepung Ketan dan Tepung Ubi Jalar Ungu Terhadap Warna ${ }^{\circ} \mathrm{Hue}$ Dodol

Keterangan:

T1= Tepung Tapioka 80\% :Tepung Ketan 10\% :Tepung Ubi Jalar Ungu 10\% T2= Tepung Tapioka 70\% :Tepung Ketan 15\% :Tepung Ubi Jalar Ungu 15\% T3= Tepung Tapioka 60\% :Tepung Ketan 20\% :Tepung Ubi Jalar Ungu 20\% T4= Tepung Tapioka 50\% :Tepung Ketan 25\% :Tepung Ubi Jalar Ungu 25\% T5= Tepung Tapioka 40\% :Tepung Ketan 30\% :Tepung Ubi Jalar Ungu 30\% T6= Tepung Tapioka 30\% :Tepung Ketan 35\% :Tepung Ubi Jalar Ungu 35\%

Gambar 5 menunjukkan bahwa adanya pengaruh yang berbeda nyata terhadap nilai oHue dodol yang dihasilkan. Dari hasil penelitian didapatkan rentang nilai oHue yaitu kisaran antara 276,28 - 282,43 (Blue Purple) dan kisaran antara 349,74360,14 (Red Purple). Nilai tersebut menunjukkan warna biru-ungu dan merah ungu. Semakin banyak rasio tepung ubi jalar ungu maka warna pada dodol semakin gelap atau semakin berwarna ungu hal ini disebabkan oleh tingginya kandungan antosianin yang terdapat pada tepung ubi jalar ungu yang menyebabkan warna ungu pada dodol.

\section{KESIMPULAN}

Berdasarkan hasil analisis serta uraian pembahasan yang terbatas pada lingkup penelitian ini maka ditarik kesimpulan sebagai berikut:

1. Perlakuan rasio tepung tapioka, tepung ketan dan tepung ubi jalar ungu memberikan pengaruh yang berbeda nyata terhadap kadar air, total antosianin, kadar gula reduksi, dan nilai oHue, namun, 
Versi Online:

http://wWw.profood.unram.ac.id/index.php/profood e-ISSN: 2443-3446

memberikan pengaruh yang tidak berbeda nyata terhadap nilai $L$ dodol.

2. Semakin tinggi penambahan tepung ubi jalar ungu, maka semakin tinggi pula total antosianin pada dodol.

3. Rasio tepung tapioka $30 \%$, tepung ketan $35 \%$ dan tepung ubi jalar ungu 35\% merupakan perlakuan terbaik dengan kadar air 24,21\%, total antosianin 8,48 $\mathrm{mg} / 100 \mathrm{~g}$, kadar gula reduksi $7,83 \%$, nilai $\mathrm{L}$ sebesar 23,85 dan nilai ${ }^{\circ}$ Hue 360,14.

\section{DAFTAR PUSTAKA}

Antarlina,S.S. 1998. Utilization of Sweet Potato Flour for Making Cookies and Cakes. (Eds), Rsearch accomplishment of Root Crops for Agricultural Development in Indonesia. Indonesia: Research institute for Legume and Tuber Crops. Jakarta.

Fadhilah, T.M. 2011. Studi Eksperimen Pembuatan Roti Tawar dengan Substitusi Ubi Jalar Ungu (Ipomea batatas). Program Pasca Sarjana Universitas Negeri Sebelas Maret. Surakarta.

Gokmen, V. Dan Senyuva, H.Z. 2007. Acrylamide Formation Is Prevented By Divalent Cations During The Maillard Reaction. Food Chemistry. 103: 196-203.

Hairani, M. 2017. Efektivitas Antioksidan Sosis Analog Tempe dengan Penambahan Tepung Ubu Jalar Ungu Terhadap Penurunan Kadar Gula Darah Mencit Diabetes. Skripsi. Universitas Mataram. Mataram.

Hanafiah, K. A. 2003. Rancangan Percobaan Teori dan Aplikasi. PT. Rajagafindo Persada. Jakarta.

Haryadi. 2006. Teknologi Pengolahan Beras. Gadjah Mada University Press. Yogyakarta.

Houston, D.F. 1972. Rice Chemistry and Technology, American Association Of Cereal "Chemist Inc. St. Paul, Minnesota

Huri A.D., Yanti M.S dan Syarifah R. 2012. Pembuatan Meuseukat Menggunakan Tepung Komposit dari Suku (Artocarpus altilis) dan Terigu
Pro Food (Jurnal IImu dan Teknologi Pangan) Vol 4 No. 2 November 2018 ISSN: 2443-1095

serta Penambahan Nenas (Ananas comosus L.). Universitas Syah Kuala. Banda Aceh.

Imanningsih, N. 2012. Gelatinisasi Beberapa Formulasi Tepung-Tepungan Untuk Pendugaan Sifat Pemasakan. Jurnal Penel Gizi Makan 35(1): 13-22.

Kelmaskosu, D. Rachel, B. Dan Febby, J.P., 2015. Pengaruh Konsentrasi Tepung Beras Ketan Terhadap Mutu Dodol Pepaya. Jurnal Teknologi Pertanian. (4)1: 22-23.

Nadia, I. 2016. Pengaruh Subtitusi Pati Ganyong (Canna Edulis Ker) Terhadap Tekstur, Komposisi Proksimat dan Daya Terima Pada Pembuatan Dodol. Publikasi IImiah. Program Studi Ilmu Gizi. Fakultas Ilmu Kesehatan. Universitas Muhammadiyah Surakarta.

Nirvana, L. 2013. Kajian Efektivitas Karaginan dari Rumput Laut Jenis Eucheuma spinosum Sebagai Edible Coating Terhadap Mutu Dodol Rumput Laut Selama Penyimpanan. Skripsi. Fakultas Teknologi Pangan dan Agroindustri. Universitas Mataram. Mataram.

Rosidah. 2010. Potensi Ubi Jalar Sebagai Bahan Baku Industri Pangan. Jurnal Teknubuga 2(2): 48.

Rumahrupute, B. dan Corneles, R. 2010. Pengaruh Konsentrasi Tepung Beras Ketan Terhadap Mutu Dodol Pala. Jurnal Pengkajian dan Pengembangan Teknologi Pertanian. 13(1): 15.

SNI 01-2891-1992. Cara Uji Makanan dan Minuman. Pusat Standarisasi Industri. Departemen Industri. Jakarta.

Soekarto, S.T. 1979. Pangan Semi Basah, Keamanan dan Potensinya dalam Perbaikan Gizi Masyarakat. Pusat Pengembangan Teknologi Pertanian IPB. Bogor.

Sri, E. Widyastuti, Lestari, D.W dan Aris, S.W. 2010. Pengaruh Substitusi Tepung Tapioka Terhadap Tekstur dan Nilai Organoleptik Dodol Susu. Universitas Brawijaya. Malang. 
Suda I, Oki, T., Masuda, M., Kobayashi, M., Nishiba, Y., dan Furuta, S. (2003). Physiological Functionality Of PurpleFleshed Sweet Potatoes Containing Anthocyanins and Their Utilization In Foods. Japan Agricultural Research Quarterly(JARQ) 37 (3): 167 - 173.

Sudarmadji, B. Haryono dan Suhardi. 1997. Prosedur Analisa Bahan Makanan dan Pertanian. Fakultas Pertanian. Universitas Gadjah Mada. Yogyakarta.

Tangketasik., I. 2013. Substitusi Tepung Tapioka (Manihot esculenta) dalam Pembuatan Dodol. Fakultas Pertanian. Universitas Sam Ratulangi. Manado.

Ticoalu, G.D.,Yunianta dan J.M. Maligan. 2016.Pemanfaatan Ubi Ungu (Ipomoea batatas) sebagai Minuman Berantosianin dengan Proses Hidrolisis Enzimatis. Jurnal Pangan dan Agroindustri 4 (1) : 45-46.

Winarno, F.G. 2004. Kimia Pangan dan Gizi. Gramedia Pustaka Utama. Jakarta.

Yahya, J.A. 2010. Kajian Pemanfaatan Tepung Ubi Jalar Ungu (Ipomoea batatas (L) Lam.) dalam Pembuatan Spreads Ubi Jalar. Skripsi. Fakultas Teknologi Pertanian. Institut Pertanian Bogor. Bogor

Yani, H.I. 2006. Karaktristik Fisika Kimia Permen Jelly dari Rumput Laut (Eucheuma spinosum dan Eucheuma cottonii). Fakultas Perikanan dan Ilmu Kelautan. Institut Pertanian Bogor. Bogor. 